\title{
Genetic Characterization and Real-Time PCR Detection of Burkholderia glumae, a Newly Emerging Bacterial Pathogen of Rice in the United States
}

Ronald J. Sayler, Department of Plant Pathology, University of Arkansas, 217 Plant Science Building, Fayetteville 72701; Richard D. Cartwright, Department of Plant Pathology and Cooperative Extension Service, 2301 South University Avenue, Little Rock, AR 72203; and Yinong Yang, Department of Plant Pathology, University of Arkansas, 217 Plant Science Building, Fayetteville 72701

\begin{abstract}
Sayler, R. J., Cartwright, R. D., and Yang, Y. 2006. Genetic characterization and real-time PCR detection of Burkholderia glumae, a newly emerging bacterial pathogen of rice in the United States. Plant Dis. 90:603-610.

Panicle blight of rice (Oryza sativa), caused by the bacterium Burkholderia glumae, is one of the most important new diseases in rice production areas of the southern United States. In this study, pathogenic strains were isolated from diseased panicles in Arkansas rice fields and examined using the Biolog GN microplate system, whole cell fatty acid methyl ester analysis (FAME), rep-polymerase chain reaction (PCR) genomic DNA fingerprinting, and 16S-23S ribosomal DNA (rDNA) intergenic transcribed spacer (ITS) sequence analysis. The B. glumae isolates from Arkansas can be divided into two major groups, but their genetic diversity was relatively low as revealed by $16 \mathrm{~S}-23 \mathrm{~S}$ rDNA ITS sequence analysis. Since no practical method existed, up to now, for testing the presence of B. glumae in rice seeds, we have developed in this study a real-time PCR method that is effective in detecting and identifying the pathogen in seed lots and in whole plants. The specific PCR primers were designed based on the 16S-23S rDNA ITS sequence of several representative isolates from Arkansas and Japan. This method is highly sensitive, rapid, and reliable, and has great potential for analyzing large numbers of samples without the need for DNA extraction or agarose gel electrophoresis. Although vertical resistance has not been observed among tested rice cultivars, LM-1 and Drew exhibited considerable resistance to B. glumae infection based on disease lesion size and the bacterial growth in planta.
\end{abstract}

Additional keywords: bacterial panicle blight, pathogen detection, seedborne disease

Panicle blight of rice (Oryza sativa), caused by the bacterium Burkholderia glumae, is a frequent cause of yield loss on certain cultivars in the southern United States and other rice growing areas around the world $(2,6-8,33)$. The pathogen also causes seedling rot in nursery boxes and is one of the most important bacterial rice pathogens in Japan (2). The pathogen is seedborne $(12,30)$ and grows epiphytically on the plant through the booting stage (13). The bacterium multiplies rapidly on the surface of emerging panicles and infects flowers just after emergence (13). Symptoms include small (1 to $5 \mathrm{~mm}$ ) tan lesions with brown margins on the leaves and spikelets, resulting in abortion of infected kernels before complete fill. Infected florets may exhibit dark gray or brown bases, but the rachis of the panicle remains green. A prominent sheath lesion several centimeters long with a tan center and reddish brown margin may form on individual flag

Corresponding author: Y. Yang

E-mail: yiyang@uark.edu

Accepted for publication 19 December 2005.

DOI: 10.1094/PD-90-0603

(C) 2006 The American Phytopathological Society leaf sheaths of infected tillers. The panicles often remain erect, due to a loss of grain weight, instead of bending over.

Currently, there is no method for control of panicle blight in the United States, but the use of clean planting seed has been effective in Japan (2). Although a conventional polymerase chain reaction (PCR) method for the detection of B. glumae in rice plants has been reported, this method is not applicable to the detection of $B$. glumae in seeds (29). In addition, this method requires a boiling step for plant extracts before PCR amplification, increasing processing time. Also, these B. glumae-specific primers are suited for conventional PCR only, as they amplify a fragment of $395 \mathrm{bp}$ in length, too long for use in real-time PCR.

Real-time PCR technology enables the detection and identification of plant pathogens in a manner that is sensitive, fast, and reliable (4). This technique allows realtime fluorescence detection of PCR amplification and records a specific cycle number, as measured by cycle threshold $(\mathrm{Ct})$, at which a statistically significant increase in the fluorescence (greater than background) can be detected. Real-time PCR provides accurate quantification, as PCR products are monitored as they accumulate in the exponential phase, before the PCR re- agents become limiting (19). It also allows the melting point of the PCR products to be measured, ensuring the specificity of the amplicon (23). Real-time PCR has the advantage of being faster and less labor intensive than conventional PCR, because agarose gel electrophoresis is not required for visualization of the PCR product. The use of real-time PCR detection is continually increasing for all plant pathogens including viruses $(3,9,21)$, fungi $(11,14$, $22,32)$, and bacteria $(20,25,26,31)$. Clearly, a real-time PCR method for detection of $B$. glumae in seeds is needed to facilitate the planting of clean seed.

In addition to planting clean seed, the use of resistant varieties for long grain cultivars is a common approach to reduce losses from disease in various rice-growing regions of the world (2). Unfortunately, all commercial medium grain cultivars currently grown in the United States are susceptible to $B$. glumae to varying degrees. Information on the relative resistance of various commercial rice cultivars and breeding lines to B. glumae is essential for plant breeders to develop rice cultivars with greater resistance to this pathogen. Field trials are currently in progress, but selection of resistant varieties will take several seasons. Therefore, a rapid and efficient assay for evaluating disease resistance in the seedling stage is needed to assist rice breeders in the selection of genotypes with resistance and incorporating this resistance into commercial cultivars.

In this study, we have isolated, identified, and characterized the B. glumae isolates from Arkansas rice fields using the Biolog GN microplate system, cellular fatty acid methyl ester (FAME) analysis, PCR-based genomic DNA fingerprinting, and 16S-23S ribosomal DNA intergenic transcribed spacer (ITS) sequence analysis. Furthermore, we have developed a realtime PCR method for pathogen detection to facilitate the planting of clean seed. To ensure that primers would be capable of detecting all isolates of the pathogen, the 16S-23S rDNA ITS sequences of several representative isolates were sequenced and compared with the ITS sequences of isolates from Japan (29) as well as of five closely related Burkholderia species. Specific primers suitable for real-time PCR analysis were designed to amplify all $B$. 
glumae isolates including the Japanese isolates but not related Burkholderia species. A simple one-step rice seed wash was employed such that the wash can be added directly to the real-time $\mathrm{PCR}$ reaction components. Furthermore, a rapid greenhouse assay was developed to screen rice lines for resistance to B. glumae in which five rice cultivars and one breeding line were evaluated.

\section{MATERIALS AND METHODS}

Bacterial strains. Bacterial strains used in this study for genetic diversity analysis, PCR primer design, and cultivar resistance evaluation are listed in Table 1.

Isolation and identification of rice pathogenic bacteria. Samples of infected rice plants were collected from commercial rice fields in Arkansas. Diseased tissue was ground in $1 \mathrm{ml}$ of filter deionized $\mathrm{H}_{2} \mathrm{O}$ $\left(\mathrm{dH}_{2} \mathrm{O}\right)$ to homogeneity with a mortar and pestle. The sample was spread on a nutrient agar (NA) plate and incubated at $28^{\circ} \mathrm{C}$ for 2 days. Isolates were selected among representative colony types from each sample and streaked onto nutrient agar plates to obtain a pure culture for pathogen identification. The isolates were maintained at $-80^{\circ} \mathrm{C}$ in fresh nutrient broth containing $15 \%$ glycerol. The pathogenicity of representative isolates was determined by suspending bacterial cells harvested from an NA plate in sterile $\mathrm{dH}_{2} \mathrm{O}$ at $10^{8} \mathrm{CFU} / \mathrm{ml}$ and infiltrating them into tobacco (Nicotiana tabacum) leaves. Strains producing hypersensitive response (HR) were considered pathogenic and infiltrated into rice leaves at $10^{8} \mathrm{CFU} / \mathrm{ml}$ to determine if the HR positive isolates were rice pathogens. Rice pathogenic strains produced symptoms of yellowing and necrosis on rice leaves 4 days after inoculation.

Identification and characterization of B. glumae isolates using Biolog, FAME, ITS DNA sequencing, and Rep-PCR fingerprinting. The genetic diversity of rice pathogenic isolates was analyzed using enterobacterial repetitive intergenic consensus sequence Rep-PCR genomic fingerprinting (18). Rep-PCR primers and PCR conditions were the same as used previously (17). The genomic DNA fragments generated from the PCR reaction were separated on a $1.5 \%$ agarose gel in a

Table 1. Bacterial strains used in this study ${ }^{\mathrm{a}}$

\begin{tabular}{|c|c|c|c|c|}
\hline Strain & Species & Origin & $\begin{array}{l}\text { Year } \\
\text { isolated }\end{array}$ & Cultivar \\
\hline Y291 & Burkholderia glumae & Arkansas & 1999 & Bengal \\
\hline Y294 & B. glumae & Arkansas & 1999 & Bengal \\
\hline 2003-02 & B. glumae & Lonoke Co. & 2003 & Francis \\
\hline $2003-05$ & B. glumae & Lonoke Co. & 2003 & Francis \\
\hline $2003-21$ & B. glumae & Lonoke Co. & 2003 & Francis \\
\hline $2003-22$ & B. glumae & Arkansas & 2003 & Bengal \\
\hline $2003-23$ & B. glumae & Arkansas & 2003 & Bengal \\
\hline $2003-24$ & B. glumae & Arkansas & 2003 & Bengal \\
\hline $2003-25$ & B. glumae & Arkansas & 2003 & Bengal \\
\hline $2003-26$ & B. glumae & Arkansas & 2003 & Bengal \\
\hline $2003-27$ & B. glumae & Arkansas & 2003 & Bengal \\
\hline $2003-28$ & B. glumae & Lonoke Co. & 2003 & Bengal \\
\hline $2003-29$ & B. glumae & Lonoke Co. & 2003 & Bengal \\
\hline $2003-30$ & B. glumae & Lonoke Co. & 2003 & Bengal \\
\hline $2003-31$ & B. glumae & Lonoke Co. & 2003 & Bengal \\
\hline $2003-32$ & B. glumae & Lonoke Co. & 2003 & Bengal \\
\hline $2003-33$ & B. glumae & Lonoke Co. & 2003 & Bengal \\
\hline $2003-34$ & B. glumae & Lonoke Co. & 2003 & Bengal \\
\hline $2003-35$ & B. glumae & Lonoke Co. & 2003 & Bengal \\
\hline $2003-36$ & B. glumae & Lonoke Co. & 2003 & Bengal \\
\hline $2003-37$ & B. glumae & Lonoke Co. & 2003 & Bengal \\
\hline $2003-38$ & B. glumae & Lonoke Co. & 2003 & Bengal \\
\hline 2003-39 & B. glumae & Lonoke Co. & 2003 & Bengal \\
\hline $2003-40$ & B. glumae & Lonoke Co. & 2003 & Bengal \\
\hline $2003-51$ & B. glumae & Lonoke Co. & 2003 & Bengal \\
\hline $2003-52$ & B. glumae & Lonoke Co. & 2003 & Bengal \\
\hline $2003-53$ & B. glumae & Lonoke Co. & 2003 & Bengal \\
\hline $2003-54$ & B. glumae & Stuttgart & 2003 & Bengal \\
\hline $2003-55$ & B. glumae & Stuttgart & 2003 & Bengal \\
\hline $2003-56$ & Burkholderia gladioli ${ }^{\mathrm{b}}$ & Poinsett Co. & 2003 & Bengal \\
\hline $92-1$ & B. gladioli $^{\mathrm{c}}$ & Georgia & 1992 & Unknown \\
\hline $01-1$ & B. gladioli $^{\mathrm{c}}$ & Toombs Co., GA & 2001 & Unknown \\
\hline LSU & Burkholderia plantarii $^{\mathrm{b}}$ & Arkansas & Unknown & Unknown \\
\hline 3549 & Burkholderia andropogonis ${ }^{\mathrm{c}}$ & Unknown & Unknown & Unknown \\
\hline $98-2$ & Burkholderia cepacia ${ }^{\mathrm{c}}$ & Georgia & 1998 & Unknown \\
\hline $99-2$ & B. cepacia $^{\mathrm{c}}$ & Georgia & 1999 & Unknown \\
\hline DH5 $\alpha$ & Escherichia coli ${ }^{\mathrm{d}}$ & n.a. & n.a. & n.a. \\
\hline
\end{tabular}

a All B. glumae strains were isolated from rice panicles collected from Arkansas.

${ }^{\mathrm{b}}$ Strain DNA provided by Charles Rush, Louisiana State University.

${ }^{\mathrm{c}}$ Strain DNA provided by Jan E. Leach, Colorado State University.

d Obtained from New England Biolabs; n.a., not applicable.

TAE buffer at $5 \mathrm{~V} / \mathrm{cm}$. Fingerprints from different strains were compared visually after ethidium bromide staining of the gel. Fragments were scored as either present or absent, and the genetic similarities were then calculated using Jaccard's coefficient of similarity. Cluster analysis was performed using unweighted pair-group method of averages (UPGMA) with NTSYSpc software version 2.10e (Exeter Software, Setauket, NY). The dendrogram was generated by the following procedure in NTSYSpc: SimQual with coefficient J, SAHN with clustering method UPGMA, and Tree-Plot.

The genus of at least two representative isolates from each DNA fingerprint type was confirmed by using whole cell fatty acid analysis (FAME) (28) (Bacterial Identification and Fatty Acid Analysis Laboratory, University of Florida, Gainesville) and by the Biolog GN microplate system (15) (Biolog Inc., Hayward, CA). To conclusively confirm the genus and species of the representative isolates, the $1-\mathrm{kb}$ fragment of the bacterial 16S-23S rDNA ITS region was amplified by PCR (forward, 5'TGCTACGAAGAGCACTCTAAG; reverse, 5'-ACATGCACTTGTTCGCTTG ACC) and cloned into the pGEM-T Easy vector (Promega Corp., Madison, WI). The $1-\mathrm{kb}$ ITS fragment from each isolate was sequenced, and these sequences were compared with those of known reference strains of B. glumae as well with all sequences in the GenBank (Bethesda, MA) using BLAST (basic local alignment search tool, see the National Center for Biotechnology Information, National Institutes of Health website for default setting) (1).

PCR primer design. B. glumaespecific PCR primers were designed by aligning the 600 -bp variable region of the $1-\mathrm{kb}$ 16S-23S rDNA ITS clones from the representative isolates and the same 16S$23 \mathrm{~S}$ rDNA ITS region of several Burkholderia species including B. glumae (GenBank accession no. D87080), B. plantarii (GenBank accession no. D87079), B. gladioli (GenBank accession no. D87081), B. caryophylli (GenBank accession no. D87084), and B. cepacia (GenBank accession no. D87083) using Vector NTI software (Info Max, North Bethesda, MD). Based on this sequence analysis, PCR primers were designed to specifically amplify the ITS region of all $B$. glumae isolates but not other Burkholderia species (forward, 5' ACG TTC AGG GAT RCT GAG CAG 3'; reverse, 5' AGT CTG TCT CGC TCT CCC GA $3^{\prime}$ ). Primer sequences were designed to have low homodimer and heterodimer potential as well as a low probability of forming a hairpin loop, using the OligoAnalyzer 3.0 software (IDT, Coralville, IA). PCR amplification yielded a fragment of $282 \mathrm{bp}$ detectable by agarose gel electrophoresis or by real-time PCR. 
Real-time PCR assay. Real-time PCR was performed using a Thermo-Fast 96well reaction plate and Thermo-Fast Caps (AB gene Epsom, Surry, UK) in the Mx3000P real-time PCR machine from Stratagene Corporation (La Jolla, CA). Each well contains a $25-\mu \mathrm{l}$ reaction mixture that includes $12.5 \mu \mathrm{l}$ of $2 \times$ SYBR Green PCR Master Mix (Qiagen, Valencia, CA) and $12.5 \mu \mathrm{l}$ primer (3 pmol each of forward and reverse primer and $1 \mu$ of bacterial cells or plant extract). Whole bacterial cells or plant extracts were tested in PCR reactions without DNA extraction using the following conditions: $95^{\circ} \mathrm{C}$ for $15 \mathrm{~min}$; 40 cycles each of $95^{\circ} \mathrm{C}$ for $15 \mathrm{~s}$, $60^{\circ} \mathrm{C}$ annealing for $30 \mathrm{~s}$, and $72^{\circ} \mathrm{C}$ extension for $15 \mathrm{~s} ; 95^{\circ} \mathrm{C}$ for $1 \mathrm{~min}$; and $55^{\circ} \mathrm{C}$ for $30 \mathrm{~s}$. A standard curve was constructed to calculate the correlation between bacterial cell numbers and the PCR $\mathrm{Ct}$ value by assaying a series of dilutions of the bacterial culture. Bacterial numbers were determined by spectrophotometric (turbidimetric) assays, followed by plate counting. The appropriate dilutions $\left(10^{0}, 10^{1}, 10^{3}\right.$, and $10^{5}$ ) of bacterial suspension were used to develop the standard curve of $\mathrm{Ct}$ value versus cell numbers.

PCR detection of $B$. glumae in seeds and plants. Detection of $B$. glumae in rice seed lots was performed by washing $2 \mathrm{~g}$ of seed (approximately 20 seeds) in $2 \mathrm{ml}$ of sterile $\mathrm{dH}_{2} \mathrm{O}$ containing $0.1 \%$ Tween 20 . The aqueous seed suspensions were mixed on a rotary shaker at $150 \mathrm{rpm}$ for $30 \mathrm{~min}$. Detection of $B$. glumae cells in rice leaves and sheaths was achieved by harvesting a 2-cm segment of leaf or sheath, weighing the sample, and grinding the tissue with 1 $\mathrm{ml}$ of sterile $\mathrm{dH}_{2} \mathrm{O}$ using a mortar and pestle. Duplicate 1- $\mu$ l aliquots were analyzed using the real-time PCR protocol described above for detection of $B$. glumae in rice seed wash and the sheath samples.

Pathogen inoculation and disease resistance evaluation. Rice cultivars Bengal, Drew, Francis, Nipponbarre, and M201, and breeding line LM-1 were evaluated for resistance to $B$. glumae using sheath and whole plant inoculations in the greenhouse. Rice sheaths were inoculated by injecting a $20-\mu \mathrm{l}$ suspension of $10^{8} \mathrm{CFU}$ of
B. glumae strainY291 into 4-week-old rice plants at $5 \mathrm{~cm}$ above the soil line. Inoculated sheaths from four plants of each cultivar were sampled 4 days after inoculation and ground, as previously described. Four sheaths per cultivar were individually analyzed, and triplicate dilution aliquots were counted per sheath at the appropriate dilution. Bacteria numbers were quantified by dilution plating onto nutrient agar plates and calculated based on per gram of sheath for each sample. For visual evaluation of resistance, 5 to 16 plants per cultivar were inoculated by spraying a $10^{8} \mathrm{~B}$. glumae suspension onto 4 -week-old rice plants to runoff and transferred to the greenhouse at $28^{\circ} \mathrm{C}$ under $14 \mathrm{~h}$ of daylight and ambient humidity. The spray inoculation gave rise to numerous (often too many to count) lesions with relatively similar numbers of lesions per leaf. As a result, the predominant lesion size (in $\mathrm{mm}$ ) was measured 2 weeks after inoculation for different rice cultivars (measured 8 to 10 lesions per plant and 8 plants per cultivar). Data analysis for all resistance tests were performed with Tukey-Kramer HSD (alpha = 0.05) using JMP 5.0.1.2 software (SAS Institute, Cary NC).

\section{RESULTS}

Identification of $\mathrm{B}$. glumae isolates using Biolog, FAME, and ITS DNA sequence analysis. A total of $29 \mathrm{~B}$. glumae isolates were isolated (Table 1) and identified by whole cell fatty acid analysis (FAME), the Biolog GN microplate system, and/or sequence analysis of the 16S23S rDNA ITS region. All three methods identified isolates to genus consistently, but only Biolog and ITS sequence analysis proved accurate in identifying isolates to species (Table 2). The rDNA ITS sequence analysis by BLAST gave consistently high scores, with B. glumae (GenBank accession no. D87080) being the highest match for all isolates tested. Biolog also identified strains as B. glumae (Table 2). The identification of bacterial strains by sequence analysis of the 16S-23S rDNA ITS and the Biolog GN microplate system are superior to FAME analysis in providing species identification for B. glumae. Both the Biolog GN microplate system and Fame analysis are subject to environmental variation, but the Biolog system appears to be more reliable in identifying $B$. glumae in this case.

Genetic diversity of B. glumae isolates analyzed by Rep-PCR. The genetic diversity of 25 isolates pathogenic on rice was analyzed by using Rep-PCR DNA fingerprint analysis using ERIC, BOX, and REP PCR primers (Fig. 1A). Twenty-two unique but closely related DNA fingerprint profiles appeared among the $25 \mathrm{~B}$. glumae isolates analyzed in this study (Fig. 1A). Cluster analysis revealed two major groups among Arkansas isolates of B. glumae, as well as two subgroups containing identical isolates (Fig. 1B). DNA sequence analysis of the ITS region of six isolates from Arkansas and one isolate from Japan revealed more than $99.5 \%$ sequence similarity among all B. glumae isolates analyzed (Fig. 2A), although all Arkansas isolates were at least 1 bp $(0.15 \%)$ different from16S-23S rDNA ITS sequence of the isolate from Japan. Takeuchi et al. (29) previously reported that all $20 \mathrm{~B}$. glumae strains isolated from diverse regions of Japan had the same 16S-23S rDNA ITS sequence. Rep-PCR was more effective in analyzing genetic diversity than rDNA ITS sequence analysis. Isolates with the same 16S-23S rDNA ITS sequence, such as 2003-24 and 2003-31 (Fig. 2A), proved to have Rep-PCR fingerprints in different subgroups (Fig. 1B). B. plantarii was the most closely related species to the $B$. glumae isolates in this study, with $90 \%$ sequence similarity at the $16 \mathrm{~S}-23 \mathrm{~S}$ rDNA ITS, followed by $B$. gladioli, B. caryophylli, and B. cepacia, respectively.

Primer specificity and PCR detection sensitivity. Sequence data from the 16S23S rDNA ITS spacer regions of all Burkholderia isolates (Fig. 2B) were aligned using Vector NTI software. A pair of specific PCR primers was designed based on the aligned sequences such that the $3^{\prime}$ end of the forward and reverse primers would match and anneal to DNA from all $B$. glumae isolates, but not to other Burkholderia species (Fig. 2B). The analysis of PCR products produced by these

Table 2. Comparison of Biolog, fatty acid methyl ester (FAME) analysis, and rDNA intergenic transcribed spacer (ITS) sequence analysis for identification of Burkholderia glumae strains

\begin{tabular}{|c|c|c|c|c|c|c|c|}
\hline \multirow[b]{2}{*}{ Strain } & \multirow{2}{*}{$\begin{array}{c}\text { Biolog sim } \\
\text { index }^{\mathbf{a}}\end{array}$} & \multirow[b]{2}{*}{ Biolog I.D. } & \multirow{2}{*}{$\begin{array}{l}\text { Fatty acid } \\
\text { sim index }\end{array}$} & \multirow[b]{2}{*}{ Fatty acid I.D. } & \multicolumn{2}{|c|}{ ITS BLAST } & \multirow[b]{2}{*}{ ITS I.D. } \\
\hline & & & & & Score & E-value ${ }^{c}$ & \\
\hline Y291 & 0.743 & B. glumae & 0.714 & B. cepacia & 1199 & 0.0 & B. glumae \\
\hline 2003-02 & 0.542 & B. glumae & 0.081 & B. серасіа & 1209 & 0.0 & B. glumae \\
\hline 2003-05 & 0.574 & B. glumae & 0.127 & B. gladioli & 1199 & 0.0 & B. glumae \\
\hline 2003-24 & 0.534 & B. glumae & 0.122 & B. gladioli & 1188 & 0.0 & B. glumae \\
\hline $2003-31$ & 0.705 & B. glumae & 0.079 & B. серасіа & 1204 & 0.0 & B. glumae \\
\hline $2003-37$ & 0.399 & B. glumae & 0.813 & B. gladioli & 1193 & 0.0 & B. glumae \\
\hline
\end{tabular}

a A Biolog similarity index greater than 0.5 is considered an exact match.

${ }^{\mathrm{b}}$ A similarity index greater than 0.8 is considered an exact match. No B. glumae fatty acid profiles were present in the database so none of the Arkansas isolates were identified as $B$. glumae by this method.

${ }^{c}$ All BLAST score values represent the highest possible match to B. glumae (GenBank accession no. D87080). An E-value of 0 is considered an exact match. 
primers confirmed their specificity for detecting representative $B$. glumae isolates but not other bacterial species (Fig. 3).

The amplification profile of several $B$. glumae dilutions generated with cycle by cycle measurement of fluorescence is shown in Figure $4 \mathrm{~A}$. The $\Delta \mathrm{Rn}$ values for the no template control (Fig. 4A) as well as plant extract and rice seed wash (data not shown) remained at baseline throughout the 40 cycles. In contrast, the $\mathrm{Ct}$ values for the $10^{5}, 10^{3}, 10^{1}$, and $10^{0}$ bacterial cell dilutions in Figure 4A were 13.72, 17.64, 24.68, and 26.12, respectively. Also, the melting curve analysis revealed a single peak at $82.5^{\circ} \mathrm{C}$ in all samples, the expected $\mathrm{Tm}$ for the 282-bp amplified fragment. These results further confirm the specific- ity and sensitivity of the primers for the 16S-23S ITS DNA sequence of B. glumae rather than rice or other bacterial DNA.

The real-time PCR with the specific primers accurately quantified $B$. glumae cells directly from diluted broth cultures in real-time PCR assays (Fig. 4B). A linear relationship was observed when $\mathrm{Ct}$ values were plotted against the log of the number

A

ERIC

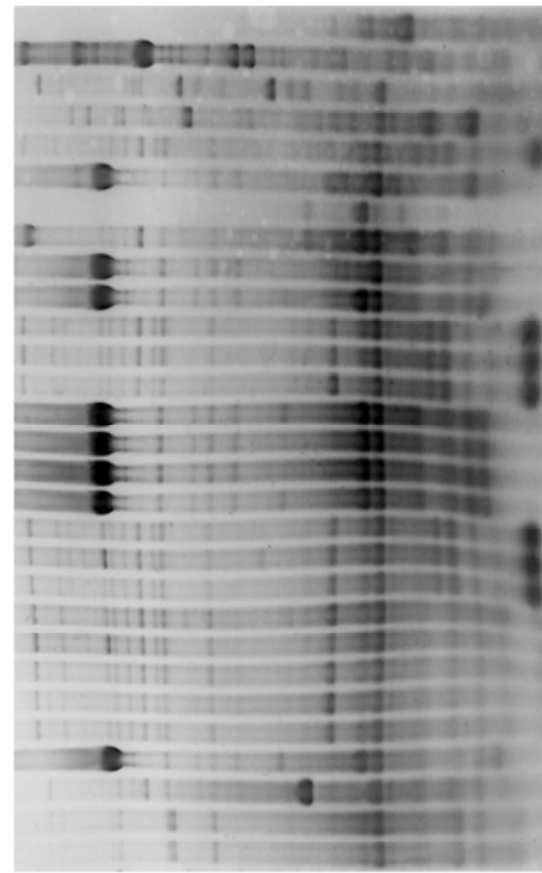

BOX

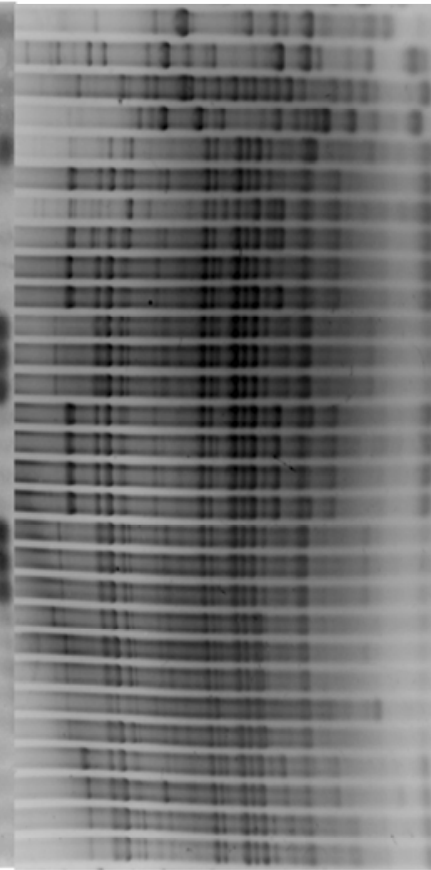

REP

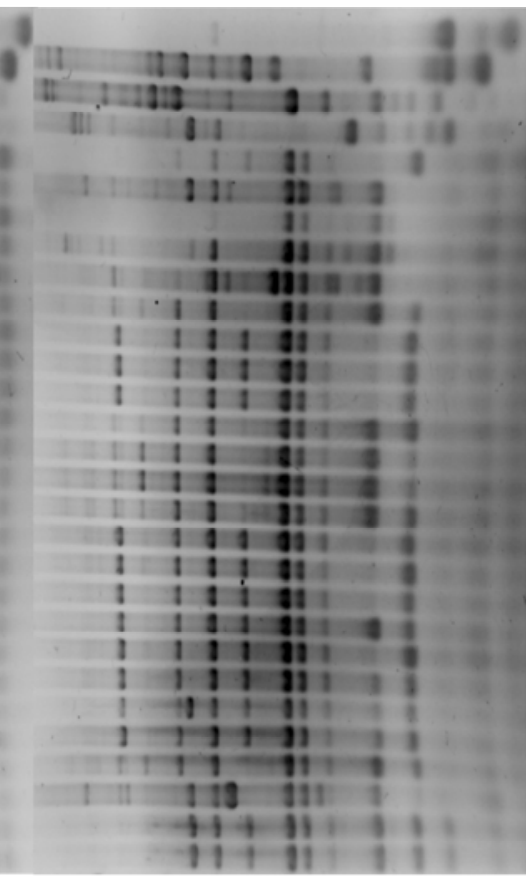

B. plantarii B. andropogonis B. cepacia B. gladioli 2003-55 2003-54 2003-53 2003-52 2003-51 2003-40 2003-36 2003-35 2003-34 2003-33 2003-32 2003-31 2003-30 2003-29 2003-28 2003-27 2003-26 2003-25 2003-24 2003-23 2003-22 2003-21 2003-05 Y294 Y291

\section{B}

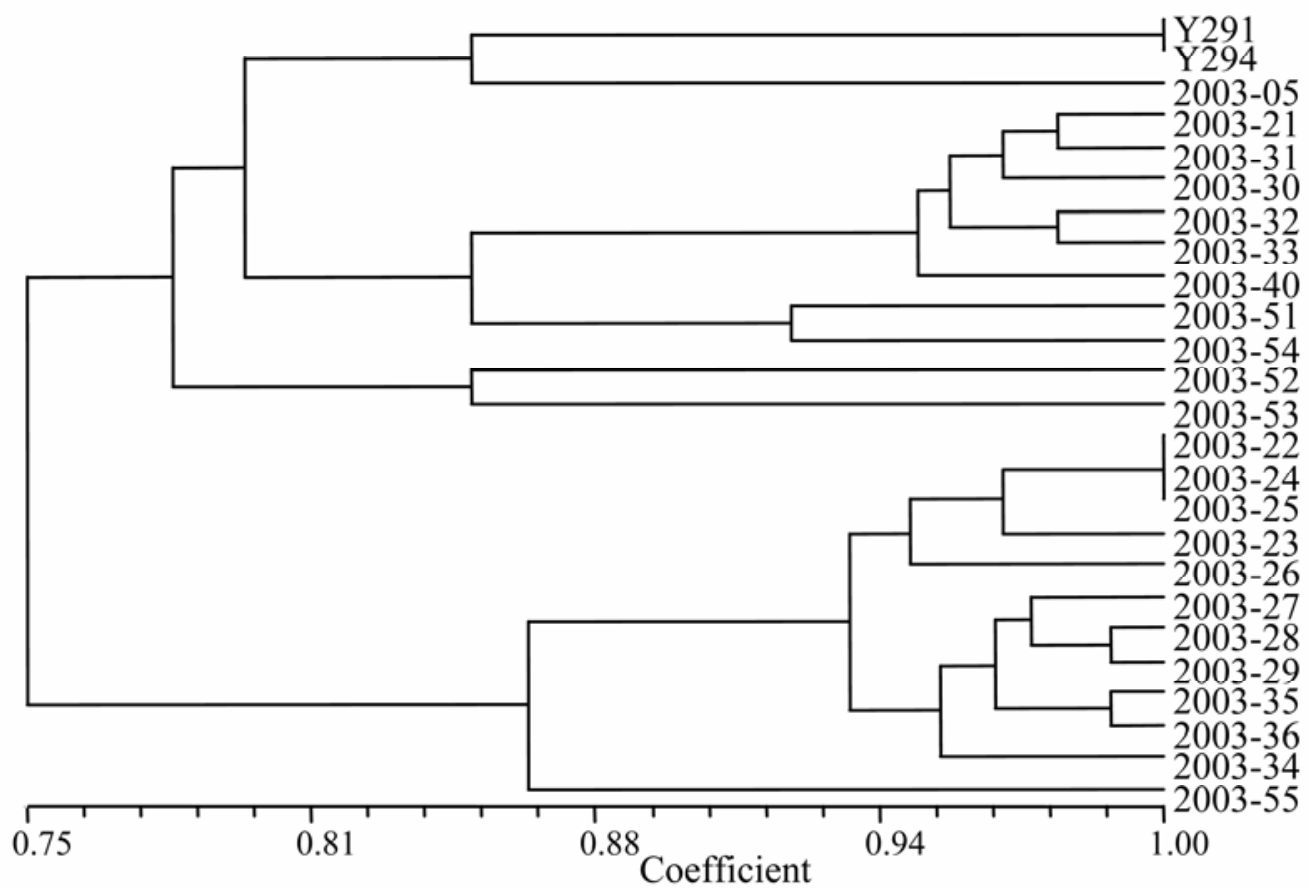

Fig. 1. Analysis of the genetic diversity of Burkholderia glumae isolates from Arkansas. A, Agarose gel electrophoresis of DNA fingerprint patterns of $B$. glumae, B. plantarii, B. andropogonis, B. cepacia, and B. gladioli strains produced by the Rep-polymerase chain reaction (PCR) primers ERIC, BOX, and REP. B, Dendrogram of DNA fingerprints generated by Rep-PCR of $B$. glumae isolates from Arkansas with similarity coefficient. 
of bacterial cells. The correlation coefficient for the standard curve was 0.98 and was consistent among several repetitions.

Real-time PCR detection of B. glumae in rice seeds and plants. Rice seeds from several sources were tested for the presence of $B$. glumae by the real-time PCR assay of aqueous wash solutions. Analysis of multiple rice seed subsamples from the same source yielded consistent results either for the detection of the pathogen or the absence of the pathogen (Table 3). Detection of $B$. glumae from inoculated rice plants was also consistent and confirmed by isolation of a rifampicinresistant marked mutant of this pathogen. The rifampicin-resistant mutant was generated from a culture of strain 2003-2 by growing on rifampicin containing nutrient agar. Plant extracts from noninoculated rice plants produced no amplification (data not shown). The correlation between bacterial numbers (determined by dilution plating) from inoculated plants $\left(R^{2}=0.66\right)$ and $\mathrm{Ct}$ values was not as high as was the case for broth culture dilutions. Quantifica- tion of living bacterial cells may be less accurate in planta than with diluted logphase broth cultures (Fig. 4B), because a significant number of bacterial cells may die in planta, especially by 4 days postinoculation (Fig. 5A). When quantifying bacterial numbers by dilution plating, only live cells are counted; conversely, real-time PCR measures amplification of template from both living and dead cells as long as DNAs are not degraded.

Evaluation of resistance to $B$. glumae. The resistance of rice cultivars Bengal,

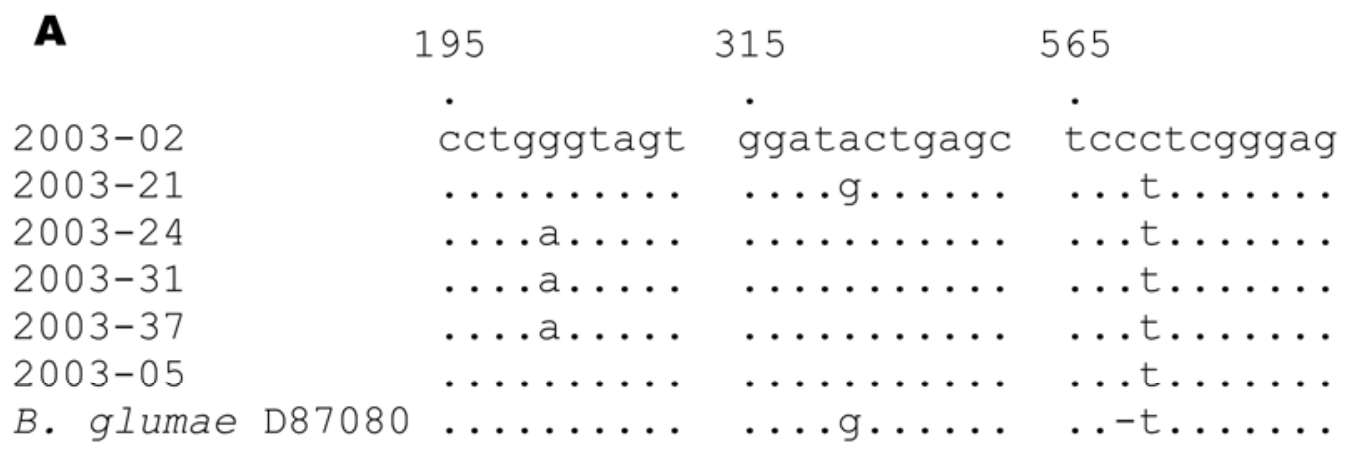

B

$2003-02$
$2003-21$
$2003-24$
$2003-31$
$2003-37$
$2003-05$
B. glumae D87080
B. plantarii
B. gladioli
B. Caryophylli
B. Cepacia

2003-02

2003-21

2003-24

2003-31

2003-37

2003-05

B. glumae D87080

B. plantarii

B. gladioli

B. caryophylli

B. cepacia $5^{\prime}$ acaаACGTTCAGG---GATACT--GAGCAGttgt $3^{\prime}$

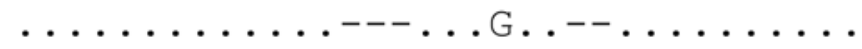

$\ldots \ldots \ldots \ldots \ldots \ldots$

$\ldots \ldots \ldots \ldots \ldots . . \ldots \ldots$

$\ldots \ldots \ldots \ldots . \ldots . \ldots . \ldots$

$\ldots \ldots \ldots \ldots . \ldots . \ldots . \ldots$

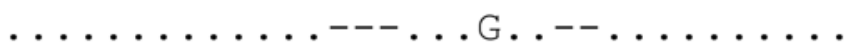

....G...GCTT---.G...C-- ..GTT.CC.

.........TCA.T. . ACTC . .TCT ...

tgctTG...TAT---...AACC...A.T..tg

tgctTG.... TAT---....АACC...A.T..tg

5' tccctCGGGAGAGCGAGACAGACTcgtt 3'

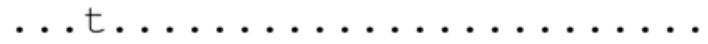

$\ldots t \ldots \ldots \ldots \ldots \ldots \ldots \ldots$

$\ldots t \ldots \ldots \ldots \ldots \ldots \ldots \ldots$

$\ldots t \ldots \ldots \ldots \ldots \ldots \ldots$

$\ldots t \ldots \ldots \ldots \ldots \ldots \ldots \ldots$

$\ldots-t \ldots \ldots \ldots \ldots \ldots \ldots \ldots$

$---------{ }^{-A}-\ldots \ldots \ldots$. . . .

---- A. С..А...........

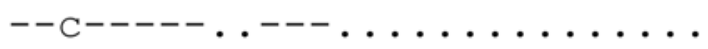

$--C^{-----. .---\ldots \ldots \ldots \ldots \ldots}$

Fig. 2. Sequence comparison of the rDNA intergenic transcribed spacer (ITS) region of Burkholderia strains. A, The sequence heterogeneity of the 16S-23S rDNA ITS from six Arkansas isolates and an isolate from Japan (GenBank accession no. D87080). B, Design of B. glumae-specific primers based on the ITS sequence comparison among the B. glumae isolates from Arkansas and Japan (GenBank accession no. D87080), B. caryophylli (D87084), B. cepacia (D87083), B. gladioli (D87081), and B. plantarii (D87079). Arrows indicate forward and reverse oligonucleotide primer sequence targets used for conventional and real-time polymerase chain reaction (PCR) assays. 
Drew, Francis, Nipponbarre, and M201, and breeding line LM-1 was evaluated. Two sets of plants were inoculated with a rifampicin-resistant mutant of 2003-02 by spray and sheath injection methods, respectively. A time course study of bacterial growth in planta revealed that bacterial numbers increased approximately two $\log$ units at 4 days after inoculation, then decreased at day six by about $1.5 \log$ units (Fig. 5A). When bacterial growth among all rice genotypes was compared at 4 days

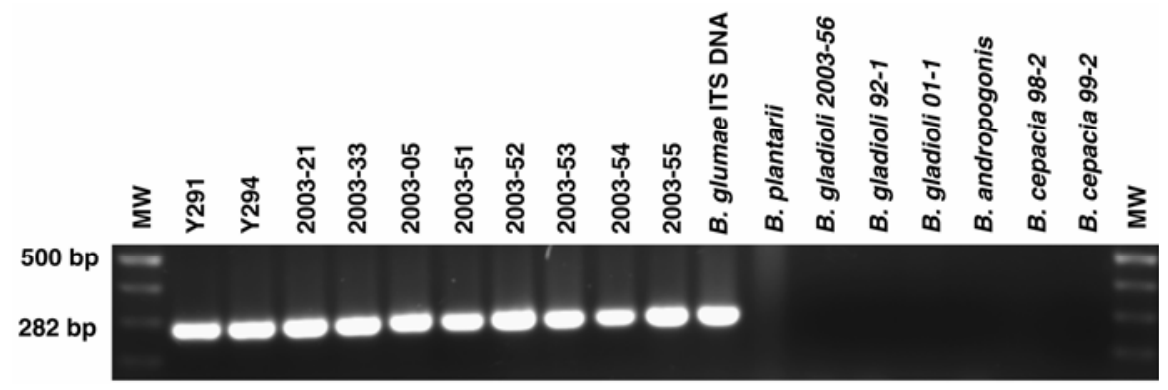

Fig. 3. Specificity of polymerase chain reaction (PCR) primers designed for the detection of Burkholderia glumae.

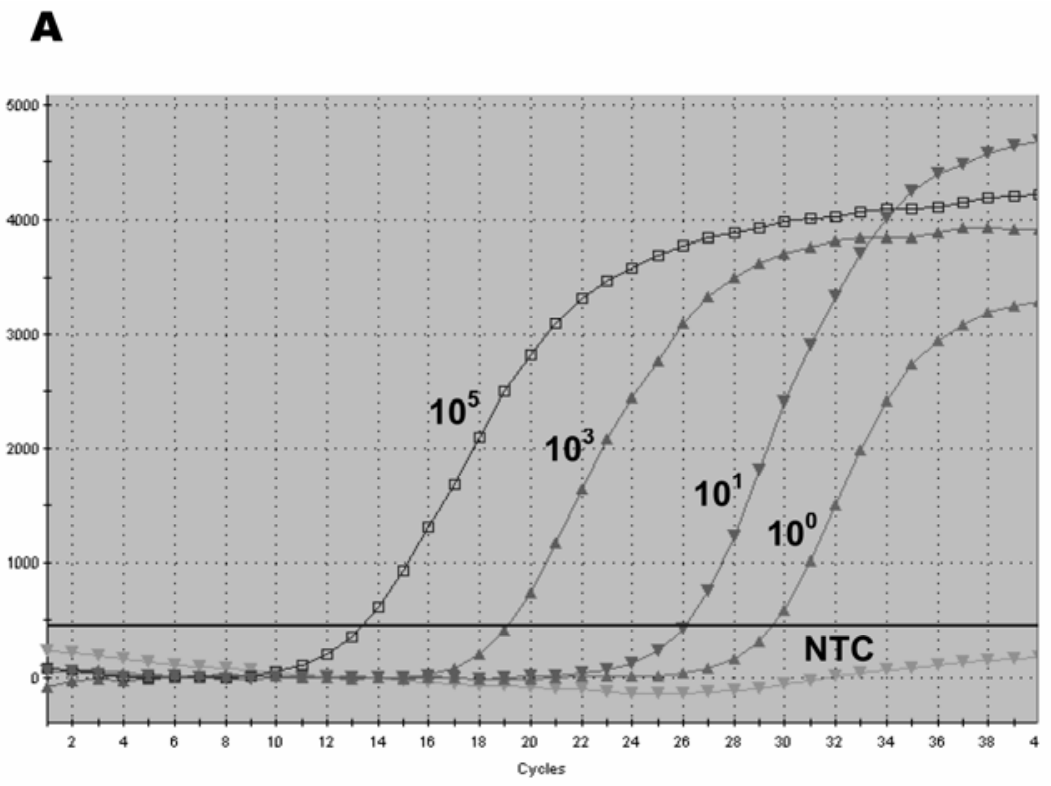

B

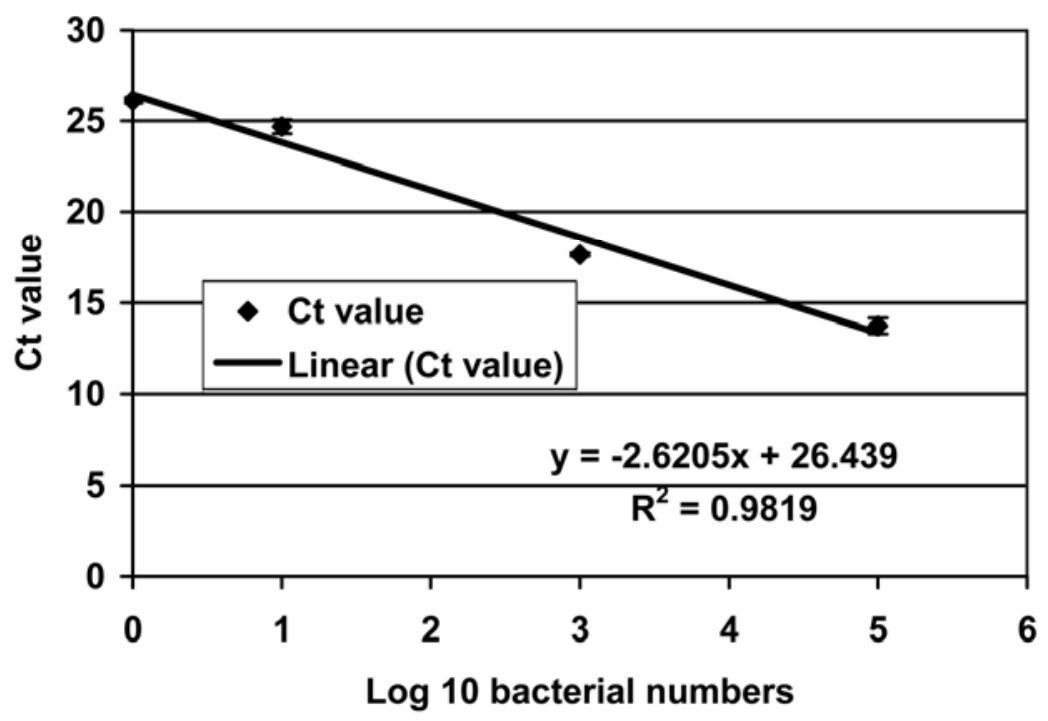

Fig. 4. Correlation between bacterial numbers and real-time polymerase chain reaction (PCR) cycle threshold (Ct). A, Representative real-time PCR fluorescent curves for four bacterial concentrations $\left(10^{5}, 10^{3}, 10^{1}\right.$, and $10^{0} \mathrm{CFU}$, respectively). B, Correlation between bacterial numbers and the $\mathrm{Ct}$ value.

after sheath injection, 'Bengal', 'Nipponbarre', and 'M201' were highly susceptible, while 'Drew' and LM-1 were relatively resistant (Fig. 5B). A similar trend occurred when plants were rated based on lesion size after spray inoculation (Fig. 5C). Given that the evaluation of rice genotypes for resistance by both lesion size and quantification of bacterial colony forming units produced the same outcome, the visual lesion measurement may be sufficient for evaluating rice lines for resistance to $B$. glumae. A time efficient and cost effective method is especially important when analyzing a large number of rice cultivars.

\section{DISCUSSION}

Panicle blight is a newly emerging rice disease in the southern United States. Yield losses of up to $30 \%$ can occur, and the disease can be epidemic in years with higher than average July and August temperatures (27). Although preliminary studies have been conducted to identify the pathogen and evaluate cultivar resistance (27), no peer-reviewed report has been published to characterize the pathogen in the United States. In this study, the pathogen was identified using multiple methods and the genetic diversity of $B$. glumae isolates from Arkansas was analyzed using 16S-23S rDNA ITS sequence analysis and Rep-PCR. Relatively low genetic diversity occurred in the $16 \mathrm{~S}-23 \mathrm{~S}$ rDNA ITS region of isolates from Arkansas with sequences being more than $99.5 \%$ identical. The genetic similarity of isolates from Arkansas was not surprising since the same ITS region of all $20 \mathrm{~B}$. glumae isolates from different regions of Japan were found to be identical (29). As expected, Rep-PCR analysis of $25 \mathrm{~B}$. glumae isolates revealed additional genetic diversity; however, isolates clustered into two main groups. Also, some isolates were found to be identical by Rep-PCR, a far more sensitive method for measuring genetic variation than $16 \mathrm{~S}-23 \mathrm{~S}$ rDNA ITS sequence analysis (18).

Table 3. Real-time polymerase chain reaction (PCR) testing of rice seed lots with Burkholderia glumae-specific PCR primers

\begin{tabular}{|c|c|c|}
\hline Sample & $\begin{array}{c}\text { Positive PCR } \\
\text { test for } \\
\text { B. } \text { glumae }^{\mathrm{a}}\end{array}$ & $\begin{array}{c}\text { Range } \\
\text { of Ct } \\
\text { values }\end{array}$ \\
\hline RREC Bengal & $10 / 10$ & $21-30$ \\
\hline Cartwright 1151 & $0 / 5$ & n.a. \\
\hline Cartwright Bengal & $0 / 5$ & n.a. \\
\hline M201 1999 & $1 / 1$ & 31 \\
\hline
\end{tabular}

${ }^{a}$ The numerator represents the number of subsamples positive for the detection of B. glumae, while the denominator represents the total number of subsamples from each seed lot.

${ }^{b}$ The cycle threshold $(\mathrm{Ct})$ is the specific PCR cycle number at which a statistically significant increase in the fluorescence (greater than background) can be detected. Lower $\mathrm{Ct}$ values indicate fewer PCR cycles necessary for detection and greater quantities of B. glumae DNA in the subsample. 
The development of a real-time PCR detection method for B. glumae in rice seeds is a crucial step in implementing a clean seed program and preventing crop losses through improved sanitation. Although a conventional PCR method for the detection of $B$. glumae in rice plants has been reported (29), to our knowledge, no method for detecting the pathogen in seeds has been reported. The method described here is highly sensitive, detecting as few as 1 to 10 cells in water, and very reliable in detecting B. glumae in plant and seed samples. The high degree of genetic similarity in the $16 \mathrm{~S}-23 \mathrm{~S}$ rDNA ITS region among the B. glumae isolates from Arkansas and Japan (29) supports the identification of isolates used in this study and the potential for these primers to detect most, if not all, isolates of the pathogen from different regions of the world. The real-time PCR assay developed in this study has several important advantages over the previous conventional PCR assay (29). First, the method described here detects the pathogen in seeds using seed wash and plant extracts directly without the preliminary extraction step. Second, real-time PCR eliminates the need for the visualization of PCR products on an agarose gel and reduces assay time from $6 \mathrm{~h} \mathrm{(29)}$ to about $2 \mathrm{~h}$ with the availability of real-time data. The real-time assay can produce both qualitative and quantitative data on $B$. glumae infection of plant and seed tissue.

In addition to the elimination of infected seed lots using real-time PCR screening, breeding for resistance is another approach for reducing disease losses to panicle blight. Field evaluations of approximately 200 rice lines for resistance to B. glumae are currently underway in Arkansas. Although a visual rating of these lines in the field for disease is effective, the selection for resistance can take several years. Using sheath injection inoculations of rice grown in the greenhouse, we found resistance to $B$. glumae appears to manifest by a reduction in bacterial multiplication and that rice lines that suppress bacterial growth showed smaller lesion size in sprayinoculated seedlings grown in the greenhouse. The agreement between these two inoculation methods suggests that visual evaluation of resistance levels (based on lesion size) of young rice plants in the greenhouse may be possible. Greenhouse trials using the spray inoculation method would be less labor intensive than sheath injection and would allow for evaluation of disease resistance all year, unlike field trials that are limited to one trial per year.

This study establishes the genetic similarity of $B$. glumae isolates from Arkansas and the first characterization of genetic diversity of isolates outside of Japan. Also, this report represents the first step in the development of rapid pathogen detection methods for rice plants and seeds. Qi and Yang (22) reported a quantitative real-time
PCR method for detecting Magnaporthe grisea, the rice blast pathogen, in infected rice plants. Work by Long et al. (16) suggests that the rice blast pathogen also is

seedborne. Recently, several reports have demonstrated that multiplex PCR allows the detection of several different pathogens in the same PCR tube $(5,10,24)$. The de-

A

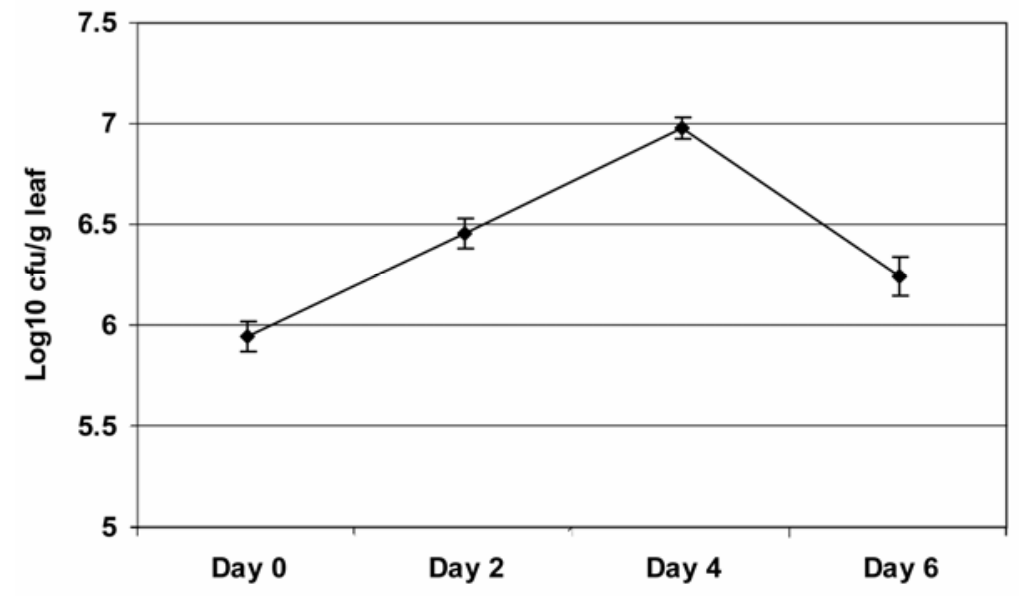

B

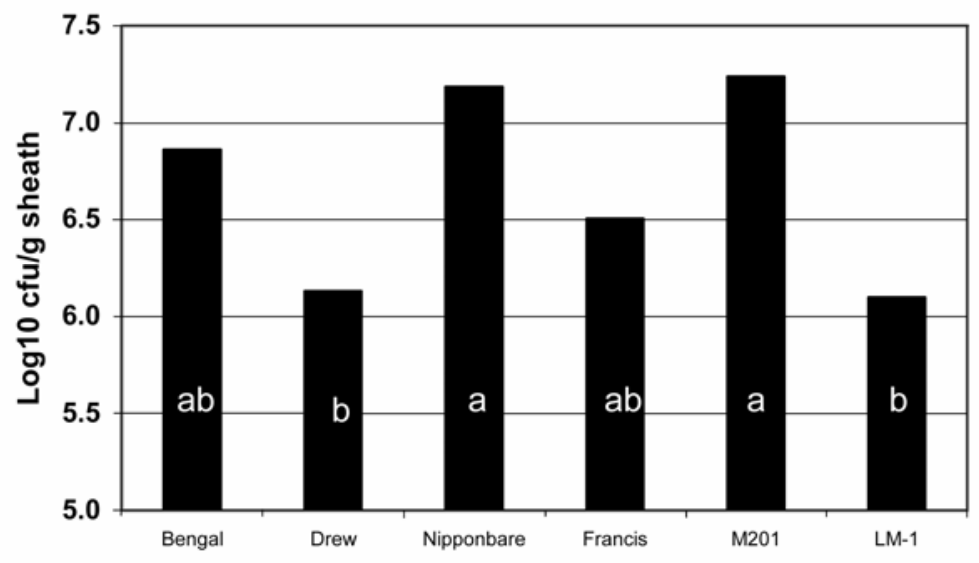

C

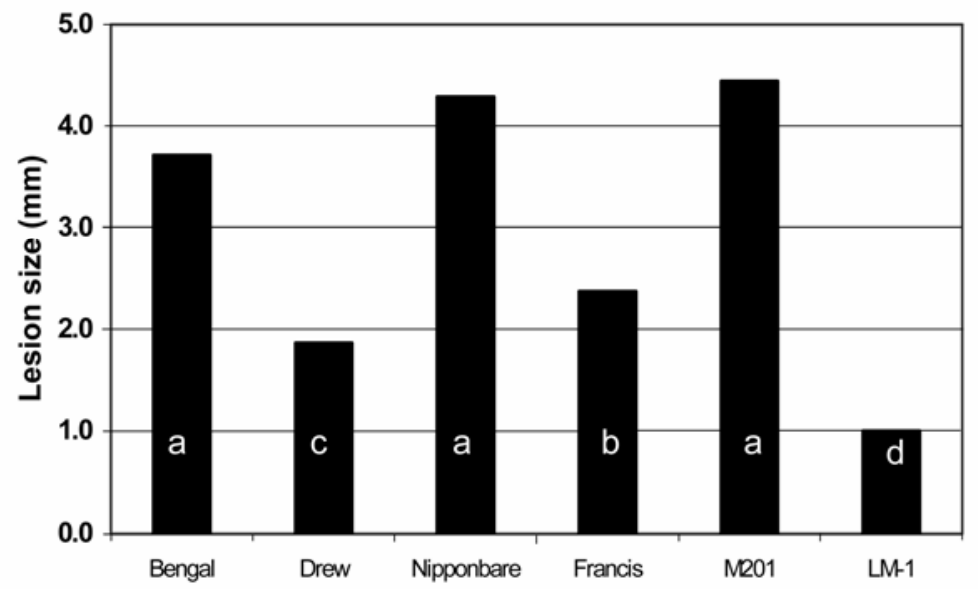

Fig. 5. Evaluation of five rice cultivars and one breeding line for resistance to Burkholderia glumae. A, Bacterial growth over time in the rice cultivar Bengal as measured by dilution plating. B, Bacterial growth in different rice cultivars 4 days after inoculation $(P=0.004)$. C, Bacterial lesion size in different rice cultivars 2 weeks after spray inoculation. Cultivars with statistically significant difference in disease severity (lesion size) were designated with different letters $(P<0.0001)$. 
velopment of PCR-based methods for screening rice seeds for all seedborne pathogens represents an achievable goal, and multiplex PCR may be the most time efficient approach for doing so in the near future. Lastly, the rapid greenhouse assay described here may be useful to breeders for the development of cultivars resistant to panicle blight.

\section{ACKNOWLEDGMENTS}

We thank M. C. Rush for providing B. gladioli and $B$. plantarii DNA as well as the reference $B$. glumae strain used in the FAME analysis. We also thank Jan E. Leach for providing B. gladioli, $B$. andropogonis, and B. cepacia DNA. We appreciate Ellen Dickstein for providing the FAME analysis. We especially thank Elizabeth Sutton for conducting numerous bacterial isolations and providing bacterial strains.

\section{LITERATURE CITED}

1. Altschul, S. F., Gish, W., Miller, W., Myers, E. W., and Lipman, D. J. 1990. Basic local alignment search tool. J. Mol. Biol. 215:403410.

2. Azegami, K., Nishiyama, K., Watanabe, Y., Kadota, I., Ohuchi, A., and Fukasawa, C. 1987. Pseudomonas plantarii sp. nov., the causal agent of rice seedling blight. Int. J. Syst. Bacteriol. 37:144-152.

3. Balaji, B., Bucholtz, D. B., and Anderson, J. M. 2003. Barley yellow dwarf virus and Cereal yellow dwarf virus quantification by real-time polymerase chain reaction in resistant and susceptible plants. Phytopathology 93:1386-1392.

4. Belgrader, P., Benett, W., Hadley, D., Richards, J., Stratton, P., Jr., and Milanovich, F. 1999. PCR detection of bacteria in seven minutes. Science 284:449-450.

5. Bertolini, E., Olmos, A., López, M. M., and Cambra, M. 2003. Multiplex nested reverse transcription-polymerase chain reaction in a single tube for sensitive and simultaneous detection of four RNA viruses and Pseudomonas savastanoi pv. savastanoi in olive trees. Phytopathology 93:286-292.

6. Cottyn, B., Cerez, M. T., Van Outryve, M. F., Barroga, J., Swings, J., and Mew, T. W. 1996. Bacterial diseases of rice. I. Pathogenic bacteria associated with sheath rot complex and grain discoloration of rice in the Philippines. Plant Dis. 80:429-437.

7. Cottyn, B., Van Outryve, M. F., Cerez, M. T., DeCleene, M., Swings, J., and Mew, T. W. 1996. Bacterial diseases of rice. II. Characterization of pathogenic bacteria associated with sheath rot complex and grain discoloration of rice in the Philippines. Plant Dis. 80:438-445.
8. Cottyn, B., Regalado, E., Lanoot, B., DeCleene, M., Mew, T. W., and Swings, J. 2001. Bacterial populations associated with rice seed in the tropical environment. Phytopathology 91:282-292.

9. Delanoy, M., Salmon, M., Kummert, J., Frison, E., and Lepoivre, P. 2003. Development of real-time PCR for the rapid detection of episomal Banana streak virus (BSV). Plant Dis. 87:33-38.

10. Dovas, C. I., Katis, N. I., and Avgelis, A. D. 2002. Multiplex detection of criniviruses associated with epidemics of a yellowing disease of tomato in Greece. Plant Dis. 86:1345-1349.

11. Filion, M., St-Arnaud, M., and Jabaji-Hare, S. H. 2003. Quantification of Fusarium solani f. sp. phaseoli in mycorrhizal bean plants and surrounding mycorrhizosphere soil using realtime polymerase chain reaction and direct isolations on selective media. Phytopathology 93:229-235.

12. Goto, K., and Ohata, K. 1956. New bacterial diseases of rice (brown stripe and grain rot). Ann. Phytopathol. Soc. Jpn. 21:46-47.

13. Goto, M. 1992. Fundamentals of bacterial plant pathology. Academic Press, San Diego, CA.

14. Guillemette, T., Iacomic-Vasilescu, B., and Simoneau, P. 2004. Conventional and real-time PCR-based assay for detecting pathogenic $\mathrm{Al}$ ternaria brassicae in Cruciferous Seed. Plant Dis. 88:490-496.

15. Jones, J. B., Chase, A. R., and Harris, G. K. 1993. Evaluation of the Biolog GN MicroPlate System for identification of some plantpathogenic bacteria. Plant Dis. 77:553-558.

16. Long, D. H., Correll, J. C., Lee, F. N., and TeBeest, D. O. 2001. Rice blast epidemics initiated by infested rice grain on the soil surface. Plant Dis. 85:612-616.

17. Louws, F. J., Fulbright, D., Stephens, C., and Bruijn, F. D. 1994. Specific genomic fingerprints of phytopathogenic Xanthomonas and Pseudomonas pathovars and strains generated with repetitive sequences and PCR. Appl. Environ. Microbiol. 60:2286-2295.

18. Louws, F., Rademaker, J., and Bruijn, F. D. 1999. The three Ds of PCR-based genomic analysis of phytobacteria: Diversity, detection, and disease diagnosis. Annu. Rev. Phytopathol. 37:81-125.

19. Mackay, I. M., Arden, K. E., and Nitsche, A. 2002. Real-time PCR in virology. Nucleic Acids Res. 30:1292-1305.

20. Mavrodieva, V., Levy, L., and Gabriel, D. W. 2004. Improved sampling methods for realtime polymerase chain reaction diagnosis of citrus canker from field samples. Phytopathology 94:61-68.

21. Nicolaisen, M. 2003. Partial molecular characterization of Dahlia mosaic virus and its detec- tion by PCR. Plant Dis. 87:945-948.

22. Qi, M., and Yang, Y. 2002. Quantification of Magnaporthe grisea during infection of rice plants using real-time polymerase chain reaction and northern blot/phosphoimaging analyses. Phytopathology 92:870-876.

23. Ririe, K. M., Rasmussen, R. P., and Wittewer, C. T. 1997. Product differentiation by analysis of DNA melting curves during the polymerase chain reaction. Anal. Biochem. 245:154-160.

24. Saade, M., Aparicio, F., Sánchez-Navarro, J. A., Herranz, M. C., Myrta, A., Di Terlizzi, B. and Pallás, V. 2000. Simultaneous detection of the three ilarviruses affecting stone fruit trees by nonisotopic molecular hybridization and multiplex reverse-transcription polymerase chain reaction. Phytopathology 90:1330-1336.

25. Schaad, N. W. 1999. Detection of Clavibacter michiganensis subsp. sepedonicus in potato tubers by BIO-PCR and an automated realtime fluorescence detection system. Plant Dis. 83:1095-1100.

26. Schaad, N. W., Opgenorth, D., and Gaush, P. 2002. Real-time polymerase chain reaction for one-hour on-site diagnosis of Pierce's disease of grape in early season asymptomatic vines. Phytopathology 92:721-728.

27. Shahjahan, A. K. M., Rush, M. C., Groth, D. and Clark, C. 2000. Panicle blight. Rice J. April:26-28.

28. Stead, D. E. 1992. Grouping of plantpathogenic and some other Pseudomonas spp. by using cellular fatty acid profiles. Int. J. Syst. Bacteriol. 42:281-295.

29. Takeuchi, T., Sawada, H., Suzuki, F., and Matsuda, I. 1997. Specific detection for Burkholderia plantarii and B. glumae by PCR using primers selected from the 16S-23S rDNA spacer regions. Ann. Phytopathol. Soc. Jpn. 63:455-462.

30. Uematsu, T., Yoshimura, D., Nishiyama, K., Ibaraki, T., and Fuji, H. 1976. Occurrence of bacterial seedling rot in nursery flat, caused by grain rot bacterium Pseudomonas glumae. Ann. Phytopathol. Soc. Jpn. 42:310-312.

31. Weller, S. A., Elphinstone, J. G., Smith, N. C., Boonham, N., and Stead, D. E. 2000. Detection of Ralstonia solanacearum strains with a quantitative, multiplex, real-time, fluorogenic PCR (TaqMan) assay. Appl. Environ. Microbiol. 66:2853-2858.

32. Winton, L. M., Stone, J. K., Watrud, L. S., and Hansen, E. M. 2002. Simultaneous one-tube quantification of host and pathogen DNA with real-time polymerase chain reaction. Phytopathology 92:112-116.

33. Zeigler, R. S., and Alvarez, E. 1990. Characteristics of Pseudomonas spp. causing grain discoloration and sheath rot of rice, and associated Pseudomonad epiphytes. Plant Dis. 74:917-922.

\section{ERRATUM}

This article was changed on June 26,2007 , on page 604 , column 3, under the heading "PCR primer design." The second sentence, with corrected primers, should read "Based on this sequence analysis, PCR primers were designed to specifically amplify the ITS region of all B. glumae isolates but not other Burkholderia species (forward, 5' ACG TTC AGG GAT RCT GAG CAG 3'; reverse, 5' AGT CTG TCT CGC TCT CCC GA 3')." The targets for the correct primers are displayed in capital letters in Figure 2B (page 607), in which the second arrow was also changed to appear over the correct letters. 